Original Research Paper

\title{
FSH Receptor and Ki-67 Protein Expressions of Endometrial Macaque in Mid-Luteal Phase after Exposure to Various Doses of Recombinant FSH and Fixed-Dose of GnRH Agonist
}

\author{
${ }^{1}$ Nurhuda Sahar, ${ }^{2}$ Ponco Birowo, ${ }^{3}$ Rosalina Thuffi, ${ }^{3}$ Andhea Debby Pradhita, ${ }^{3}$ Wa Ode Zulhulaifah, \\ ${ }^{4}$ Raden Muharram, ${ }^{5}$ Rijal Subahar, ${ }^{6}$ Fatmawaty Yazid, ${ }^{7}$ Supri Irianti Handayani and ${ }^{8}$ Vivitri Dewi \\ Prasasty
}

${ }^{1}$ Department of Medical Biology, Faculty of Medicine, Universitas Indonesia, Jakarta, Indonesia

${ }^{2}$ Departement of Urology, Faculty of Medicine, Universitas Indonesia, Jakarta, Indonesia

${ }^{3}$ Master Program of Biomedical Sciences, Faculty of Medicine, Universitas Indonesia, Jakarta, Indonesia

${ }^{4}$ Department of Obstetrics and Gynecology, Faculty of Medicine, Universitas Indonesia, Jakarta, Indonesia

${ }^{5}$ Departemen of Parasitology, Faculty of Medicine, Universitas Indonesia, Jakarta, Indonesia

${ }^{6}$ Department of Medical Chemistry, Faculty of Medicine, Universitas Indonesia, Depok, Indonesia

${ }^{7}$ Department of Anatomical Pathology, Faculty of Medicine, Universitas Indonesia, Jakarta, Indonesia

${ }^{8}$ Faculty of Biotechnology, Atma Jaya Catholic University of Indonesia, Jakarta, Indonesia

Article history

Received: 01-01-2021

Revised: 15-04-2021

Accepted: 20-05-2021

Corresponding Author:

Wa Ode Zulhulaifah

Master Program of Biomedical

Sciences, Faculty of Medicine,

Universitas Indonesia, Jakarta,

Indonesia

Email: dzulhulaifah@gmail.com
Abstract: There are many advances in Assisted Reproductive Technologies (ARTs). However, implantation rates are still low. The embryo implantation is a mutual interaction between the blastocyst and endometrium. This study aimed to investigate the endometrial cell proliferation stimulated by recombinant Follicle-Stimulating Hormone (rFSH) in various doses by looking at FSH-Receptor (FSHR) and Ki-67 protein expressions. The studied samples were Stored Biological Materials (SBMs) from the endometrial tissue of Macaca nemestrina. All sample was obtained from fifteen macaques, divided into four groups, which three groups were treated with $\mathrm{rFSH}$ and given fixed-dose $(160 \mu \mathrm{g} / \mathrm{day})$ of Gonadotropin-Releasing Hormone (GnRH) agonists and one control group as normal group. The three treated macaque groups were stimulated with 30, 50 and $70 \mathrm{IU}$ doses of rFSH. There was no significant difference in various doses of rFSH towards FSHR and Ki-67 expressions in endometrial tissue of $M$. nemestrina. Therefore, this result did not significantly correlate FSHR and Ki-67 expressions in the endometrial tissue of M. nemestrina after rFSH administration. Moreover, the highest $\mathrm{rFSH}$ dose did not reduce the FSHR and Ki-67 expressions and there was no correlation between FSHR and Ki-67 expressions. It can be concluded that macaque endometrial cells were receptive to the given dosages of $\mathrm{rFSH}$.

Keywords: FSHR, rFSH, Endometrial Tissue, Proliferation Marker, Macaque

\section{Introduction}

Implantation failure is still one of the main factors that limit the success of in vitro Fertilization (IVF) (Simon and Laufer, 2012). Embryo implantation is a complex process that requires proper crosstalk between the embryo and endometrium (Cross et al., 1994; Massimiani et al., 2020). The IVF program success rate is still low at around 5-36\% (Al-Inany et al., 2007; Fauser, 2019). Two main factors play a role in the success of IVF, including oocyte quality and endometrial receptivity when receiving blastocyst implantation in the endometrium (Simon et al., 2000; Sakiner et al., 2018).
Controlled Ovarian Hyperstimulation $(\mathrm{COH})$ is one of the procedures for giving ovarian stimulator regimens widely used to treat patients taking IVF (Gallos et al., 2017; Jungheim et al., 2015). $\mathrm{COH}$ procedure aims to stimulate the growth and maturation of many follicles simultaneously (Jungheim et al., 2015). This procedure involves administering a drug such as GonadotropinReleasing Hormone (GnRH) agonist and recombinant Follicle-Stimulating Hormone (rFSH) (Macklon et al., 2006). The maximum number of oocytes obtained is an attempt to compensate for biological limitations and laboratory errors that may occur at the next IVF stage 
(Fauser et al., 2005). However, the use of gonadotropins in $\mathrm{COH}$ procedures can negatively affect the endometrial maturation of the implantation period (Kolibianakis et al., 2002; Sahar et al., 2019). It happens because gonadotropins increase progesterone and estradiol hormones in the blood serum (Lai et al., 2009).

The administration of high-dose of $\mathrm{rFSH}$ during assisted reproductive procedures has a good impact on follicular growth (Marci et al., 2013). However, the effects on endometrial cell proliferation and receptivity have not been explained. Our previous study revealed that after a fixed-dose administration of GnRH agonist and various $\mathrm{rFSH}$ doses, $60 \%$ of the implantation window was closed (Sahar et al., 2019). However, it is currently unknown the impact of high-dose of rFSH administration on Follicle-Stimulating Hormone Receptor (FSHR) and $\mathrm{Ki}-67$ protein expression on endometrial cell proliferation, which is one of the important determinants of implantation window. The purpose of this study was to analyze the development of Macaca nemestrina endometrium after $\mathrm{COH}$ by assessing the expression of cell proliferation markers and their correlation with the expression of FSHR and Ki-67 protein.

\section{Materials and Methods}

\section{Animal}

The animal models used in this study were Macaca nemestrina (Southern pig-tailed macaques). There are 15 female macaques of reproductive age (8-10 years, body mass of $10-15 \mathrm{~kg}$ ) with a history of producing offspring. The number of $M$. nemestrina samples was limited due to ethical concerns (Ethical letter number: 1441/UN2.F1/ETIK/XII/2018).

\section{The Procedure of Controlled Ovarium Hyperstimulation ( $\mathrm{COH})$}

These macaques were divided into five groups according to their $\mathrm{COH}$ protocols, including a group of $\mathrm{GnRH}$ agonist administration with a dose of $160 \mu \mathrm{g} /$ day; groups of rFSH with dosages of 30, 50, 70 and a control group. GnRH agonist and $\mathrm{rFSH}$ were given once a day for 14 days and 12 days during the mid-luteal phase. Ovulation stimulation was conducted by administering human Chorionic Gonadotropin (hCG), which was only authorized if the macaques menstrual and ovarian cycles were successfully stabilized by the $\mathrm{COH}$ protocol as depicted in Fig. 1. All macaque was sacrificed by anesthetizing procedure with ketamine at a dose of 0.1 $\mathrm{mL} / \mathrm{kg}$ body weight on day $20-22$ of the mid-luteal phase and all endometrial tissue was collected.

Tissue dissection followed a necropsy protocol, in which the uterus was rinsed with Phosphate Buffer (PBS) and a portion of tissue was incubated in a $10 \%$ formalin solution and embedded in paraffin blocks for further analysis.

\section{Immunohistochemical (IHC) Preparation for FSH Receptor and Ki-67 Protein}

The tissue in paraffin blocks was cut with a thickness of $3.5 \mu \mathrm{m}$. The tissue was affixed to the glass object, which was coated with aminopropyl triethoxysilane (Apex). The tissue on the object-glass was initialized in xylene and washed with the multilevel alcohol series (70, 80 , 90 and $96 \%$ ethanol, respectively), followed by washing using running water. After washing, the slide was dipped into a methanol solution containing $0.5 \%$ of $\mathrm{H}_{2} \mathrm{O}_{2}$ for $30 \mathrm{~min}$ and washed with running water.

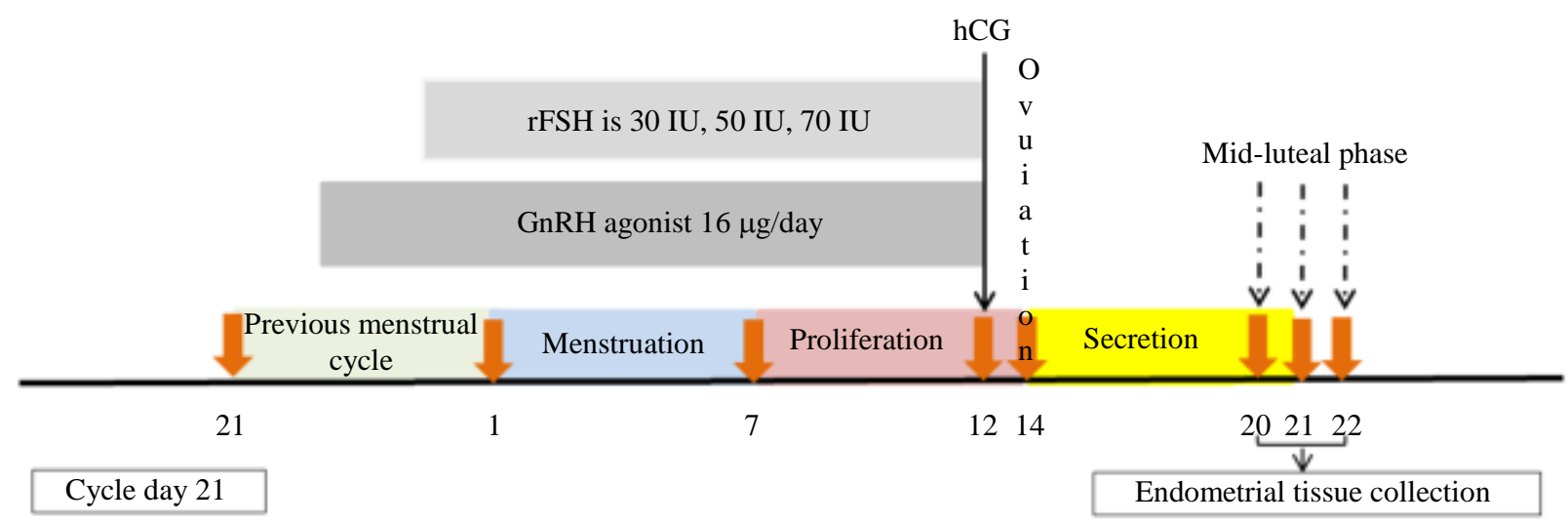

Stimulation day

Fig. 1: The procedure of Controlled Ovarium Hyperstimulation $(\mathrm{COH})$ 
The appearance of tissue antigens was done by heating the slide in sodium citrate buffer $(10 \mathrm{mmol} / \mathrm{L}, \mathrm{pH}$ 6.0) for 20 $\min$ at $98^{\circ} \mathrm{C}$. Endogenic peroxidase was inhibited by using $3 \%$ hydrogen peroxidase (in $50 \%$ methanol or $50 \%$ water) for $5 \mathrm{~min}$, then incubated at room temperature with $5 \%$ blocking serum in a fume hood for $30 \mathrm{~min}$. The slides were incubated with $\mathrm{Ki}-67$ mouse monoclonal antibodies with a $100 \mu \mathrm{g} / \mathrm{ml}$ concentration at $1: 200$ dilution at $4^{\circ} \mathrm{C}$ overnight. Likewise FSHR, slides were incubated with FSHR monoclonal antibodies from mice (clone code: FSHR/1400) with concentrations of $1-2 \mu \mathrm{g} / \mathrm{mL}$ for $30 \mathrm{~min}$. The next day, the slide was added with a second antibody and streptavidin-biotin-peroxidase complex. The chromogen Diaminobenzidine (DAB; Sigma Chemical) was added and stained with hematoxylin and then it was washed in running water and covered with entellan.

\section{Assessment of Endometrial Histology}

Assessment of Capping Protein Interaction (CPI) was carried out under a light microscope (binocular) with a magnification of 400 times. The assessment of the color intensity of each sample was carried out at five fields of view. The CPI assessment of the FSHR was based on the intensity of brown color in the epithelial cells of the endometrium and it was done manually by two expert observers. The cell counter plugins of Image $\mathbf{J}$ were used to count positive cells. Each field of view has a minimum of 100 cells. The result of two observers then analyzed using a t-test based on data distribution. No significance on the intensity resulted. Thus it could be calculated as a mean and used as H_score. Similar to the CPI assessment of $\mathrm{Ki}-67$, it was done using Image $\mathrm{J}$ software with IHC profiler plugin, a plugin to analyze the CPI output results using computerized color deconvolution color intensity. Thus, it processed the intensity values automatically for each cell.

The interpretation of that protein was made semiquantitatively using the formula of $\mathrm{H}$ _score that was calculated using the following equation: ${ }_{\mathrm{H}} \_$score $=\Sigma \mathrm{Pi}(i$ +1 ), where $\mathrm{Pi}$ is the percentage of stained cells, varying from 0 to $100 \%$ and it is the intensity of staining with a score of 1, 2 and, 3 is equal to weak, moderate and strong, respectively (Sahar et al., 2019a).

\section{Data Analysis}

Statistical analysis was performed using SPSS 25.0 (IBM Corporation). Data were analyzed parametrically by ANOVA and non-parametrically by KruskalWallis, where the value of $p<0.05$ was considered as statistically significant.

\section{Results}

The expression of FSHR in the endometrium midluteal phase of Macaca nemestrina was detected in the cytoplasm and membrane cell of the stromal cells; and cytoplasm of glandular epithelial cells (Fig. 2). Strong immunoreactivity was seen in the cytoplasm of glandular epithelial cells.
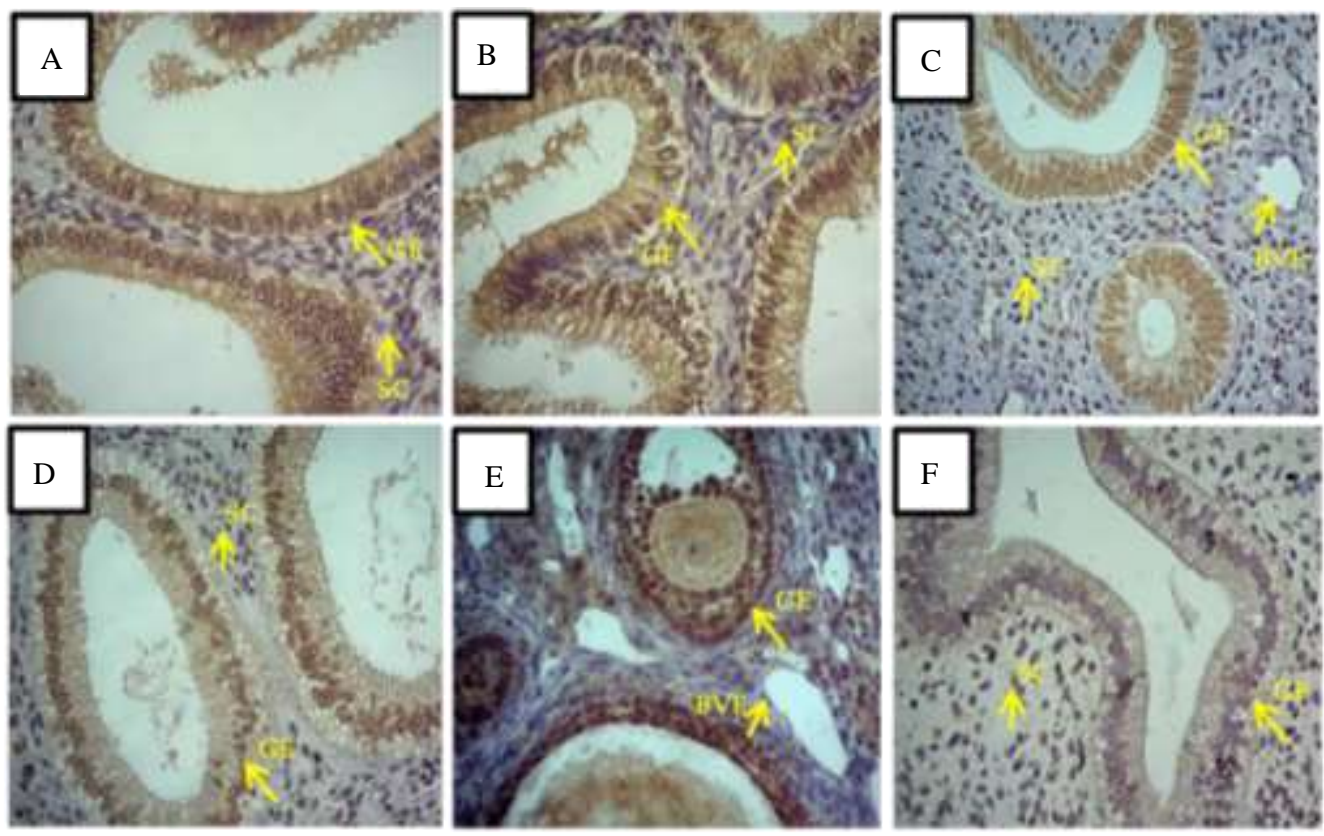

Fig. 2: Immunohistochemical staining of FSHR at the GE cytoplasm of the Macaca nemestrina endometrium. (A) Control group; (B) rFSH treatment at $30 \mathrm{IU}$; (C) rFSH treatment at $50 \mathrm{IU}$; (D) rFSH treatment at $70 \mathrm{IU}$; (E) Positive control of MCF7 breast cancer cells showed a positive response to anti-FSHR; and (F) Negative control of endothelial cell showed a negative response to antiFSHR. The optical magnification was 400x. BVE: Blood Vessel Endothelium; GE: Glandular Epithelium; SC: Stromal Cell 

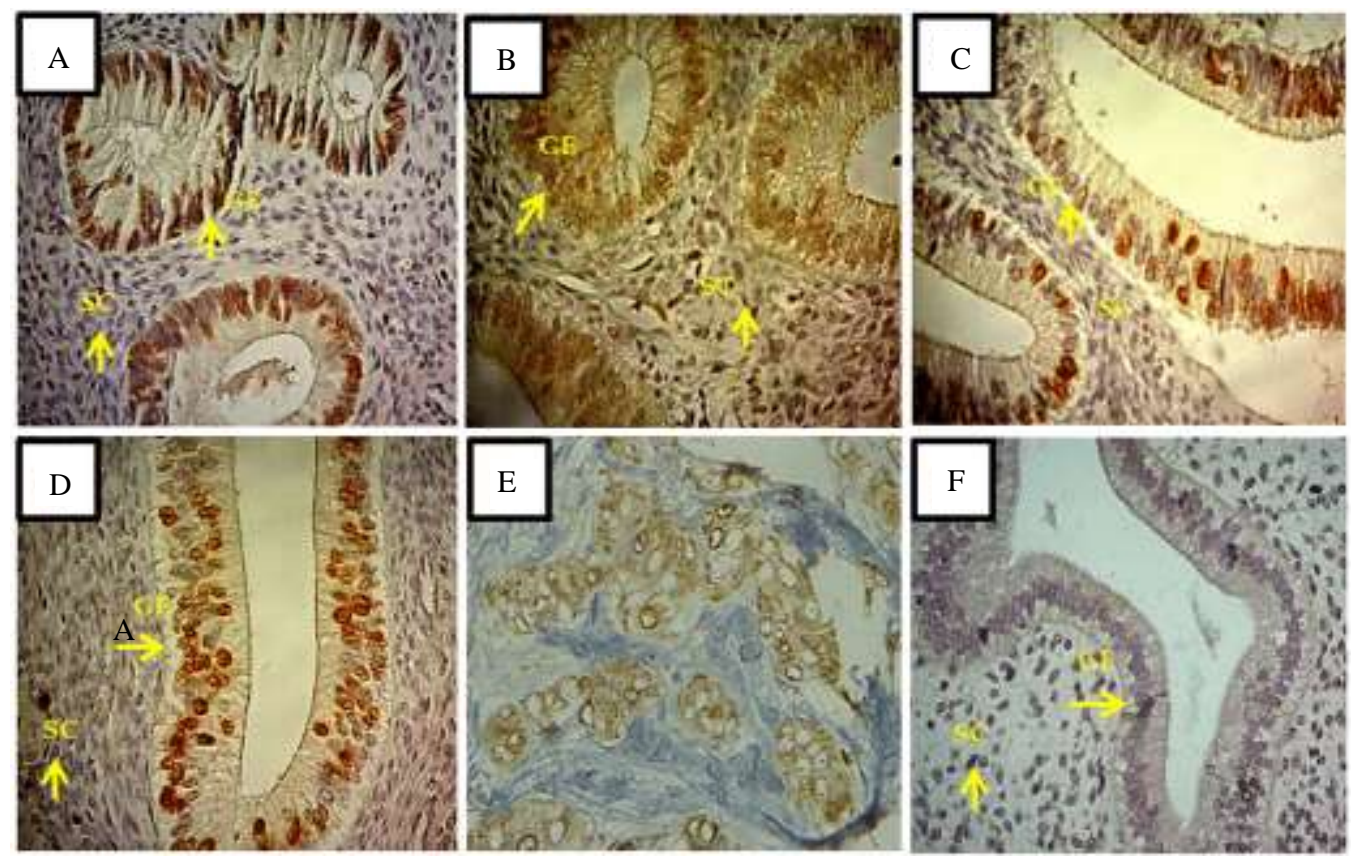

Fig. 3: Immunohistochemical staining of Ki-67 at the GE nucleus of the Macaca nemestrina endometrium. (A) Control group; (B) rFSH treatment at $30 \mathrm{IU}$; (C) rFSH treatment at $50 \mathrm{IU}$; (D) rFSH treatment at $70 \mathrm{IU}$; (E) Positive control of MCF7 breast cancer cells showed a positive response to anti-Ki-67; and (F) Negative control of endothelial cell showed a negative response to antiKi-67. The optical magnification was 400x. GE: Glandular Epithelium; SC: Stromal Cell

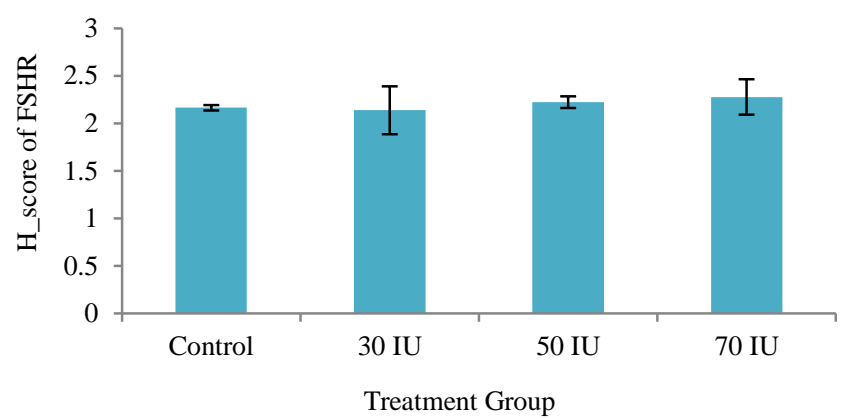

(a)

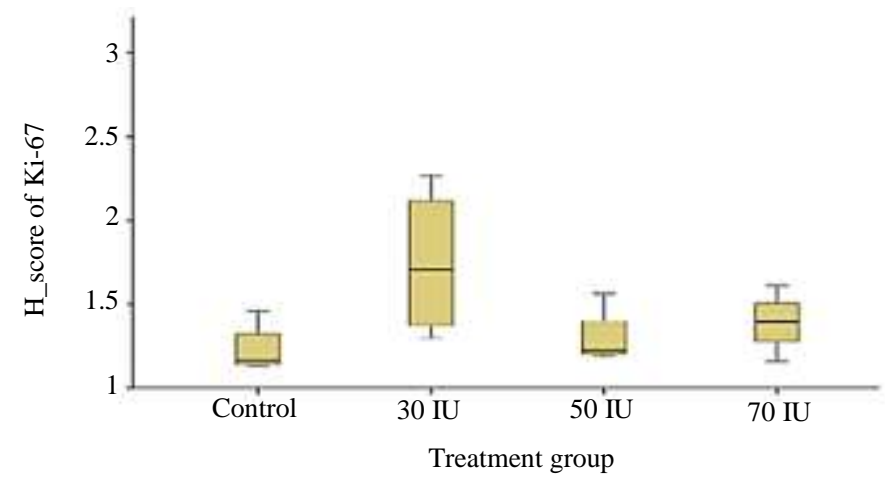

(b)

Fig. 4: H_score of endometrial protein expressions. (a) H_score value \pm SD of FSHR expressions between groups; (b) H_score value \pm SD of Ki-67 expressions between groups 


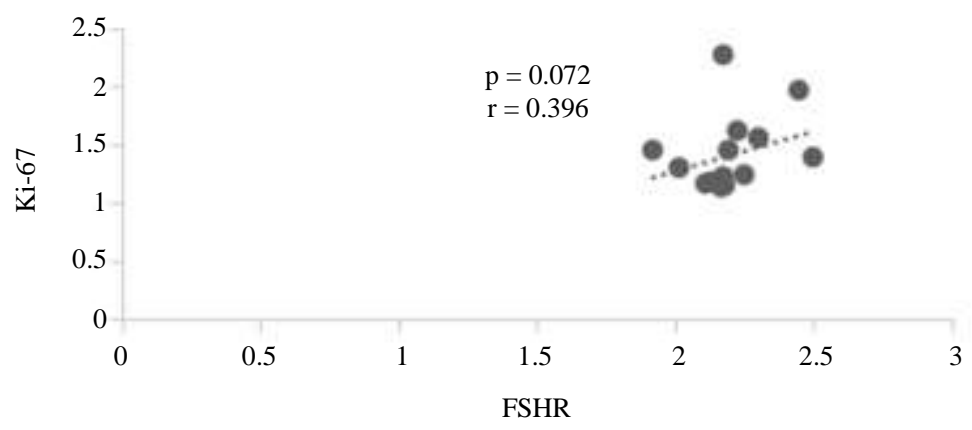

Fig. 5: Correlation between the average value of FSHR scores and Ki-67 scores

The immunolocalization of Ki-67 protein expressions in the mid-luteal phase of Macaca nemestrina endometrium was detected in the nucleus of the glandular epithelial cells and stromal cells (Fig. 3). However, strong immunoreactivity was found in the nucleus of glandular epithelial cells.

The average FSHR expressions amongst three groups in a different dose of rFSH treatments were found as dosedependent in the stimulated cycle group compared to the normal cycle group, although the Kruskal-Wallis test showed no significant differences $(p=0.642)$ between each group, as shown in Fig. 4.

Likewise, the H_score value of Ki-67 expression in the stimulated cycle also did not show a significant difference between each group (Fig. 5).

The mean test result between doses of FSHR and Ki-67 protein expressions was shown no significantly different $(p$ $=0.961$ ) from the expression of Ki-67 in each group (Fig. 5). The correlation test between FSHR expression and Ki-67 protein expression showed no significant difference $(p=$ $0.061)$. Thus, there was no significant relationship between the level of FSHR expression and the decrease of Ki-67 protein expression in each group.

\section{Discussion}

This study showed no significant differences between the higher rFSH doses and the decrease in FSHR expressions. However, FSHR expression was higher at 70 IU stimulation dose than 30 and 50 IU stimulation doses and the control group. This study followed Ponikwicka et al., which performed using endometrial tissue culture presented at $100 \mathrm{IU} / \mathrm{L}$ of $\mathrm{rFSH}$. It was reported that FSHR expression in the endometrium had increased compared to controls (Sakiner et al., 2018). Other researchers reported that FSH and other growth factors were considered to play a role in the FSHR regulation (Ponikwicka-Tyszko et al., 2016; La Marca et al., 2005).

The samples taken in the secretory phase of the menstrual cycle of endometrium referred to PonikwickaTyszko et al. (2016) and La Marca et al. (2005), the FSH receptors were more commonly found in the secretory phase. More expression of FSH receptors in the secretory phase confirmed the assumption that FSHR is regulated by progesterone (La Marca et al., 2005). In addition to the FSH hormone, the progesterone hormone is thought to regulate FSHR expression. A previous study reported that the progesterone hormone level in the secretory phase increased compared to the final follicular phase (Lawrenz and Fatemi, 2017). The progesterone increased levels in the mid-luteal phase may trigger the increasing FSHR expression (Sahar et al., 2019a).

Another study reported that a low dose of rFSH at 4 IU/day in female rats could increase FSHR mRNA expression regulation, while a high dose of $\mathrm{rFSH}$ at 20 IU/day can deregulate FSHR gene expression in the ovary. Low-dose of FSH may increase the number of FSH binding sites in the ovary, together with an increase in FSH receptor mRNA. High-dose of FSH could reduce FSH receptor binding ability and decrease mRNA levels, emphasizing gene expression and internalizing receptors on female ovaries (Simoni et al., 1997). Certain doses of FSH can increase FSHR expression, but high doses are thought to suppress FSHR expression through negative feedback as the response rate of FSH is too high. Thus, it suppresses the FSHR mRNA synthesis. In contrast, our result may be different from the previous report because the used pathway is different or can be caused by insufficient doses to provide negative feedback (LaPolt et al., 1992).

The sampling was carried out a week after the last rFSH exposure. Thus it might be unclear whether FSHR expressed in the secretory phase was affected by the various rFSH dose or the endogenous FSH. The pattern of FSH hormone levels in the blood before $\mathrm{rFSH}$ administration (day 2), last day of administration (day 12) and sampling time (day 21) showed an increase of FSH in blood in 12-13 days, then FSH decreased during sampling time (day 21). This limitation might affect the data analysis, which showed no significant difference.

The high doses of rFSH tended to reduce Ki-67 protein expression even though there was no significant difference. FSH is known to induce aromatase activity. The aromatase transcription gene is also found in the endometrium of infertile patients (Brosens et al., 2004). Therefore, FSH plays a vital role in endometrial 
aromatase synthesis by inducing local endometrial estrogen. Local estrogen production is thought to play an important role in endometrial remodeling. Therefore, the endometrium becomes receptive during the implantation period (Fujiwara, 2009; Van Mourik et al., 2009).

In line with previous studies, Zhang et al. (2015) reported using rodent models that low rFSH doses $(0.15$ IU) could reduce the size and weight of mice uterus. Other in-vitro experiments on endometrial cells were carried out using different rFSH doses of 50,100 and $150 \mathrm{IU}$, which can significantly inhibit proliferation by decreasing c-Jun expression regulation and increasing caspase regulation 3/8/9 expression to activate cell apoptosis (Zhang et al., 2015). Ku et al. (2002) performed that FSH might suppress proliferation in endometrial stromal cells.

This study revealed that FSHR expression did not significantly affect Ki-67 expression. These results suggest that FSHR may not be involved in the regulation of proliferative suppression by high doses of rFSH stimulation.

\section{Conclusion}

It was found that there was no correlation significantly between FSHR expression and Ki-67 expressions in endometrial Macaca nemestrina. Higher rFSH doses did not reduce FSHR and Ki-67 expressions. Thus, macaque endometrial cells were receptive to the given dosages of $\mathrm{rFSH}$.

\section{Acknowledgment}

We would like to thank the Director of Research and Public Services Universitas Indonesia for financial support.

\section{Funding}

This research was financially supported by Universitas Indonesia under the PITTA grant 2018 and PDUPT grant 2020 from the Ministry of Research, Technology and Higher Education of the Republic of Indonesia.

\section{Author Contributions}

Nurhuda Sahar and Rosalina Thuffi contributed to the conceptualization, methodology, validation, supervision, writing-original draft preparation, review and editing.

Ponco Birowo, Andhea Raden Muharram, Zulhulaifah Wa Ode, Rijal Subahar, Fatmawaty Yazid, Supri Irianti Handayani and Vivitri Dewi Prasasty: Conduted formal analysis, data curation, writing-original draft preparation, review and editing.

\section{Ethics}

The Research Ethics Committee approved all the experimental protocols with macaque models of
Faculty of Medicine Universitas Indonesia (1441/UN2.F1/ETIK/XII/2018).

\section{References}

Al-Inany, H. G., Abou-Setta, A. M., \& Aboulghar, M. (2007). Gonadotrophin-releasing hormone antagonists for assisted conception: a Cochrane review. Reproductive Biomedicine Online, 14(5), 640-649. https://doi.org/10.1016/S1472-6483(10)61059-0

Brosens, J., Verhoeven, H., Campo, R., Gianaroli, L., Gordts, S., Hazekamp, J., ... \& Brosens, I. (2004). High endometrial aromatase P450 mRNA expression is associated with poor IVF outcome. Human Reproduction, 19(2), 352-356. https://doi.org/10.1093/humrep/deh075

Cross, J. C., Werb, Z., \& Fisher, S. J. (1994). Implantation and the placenta: key pieces of the development puzzle. Science, 266(5190), 1508-1518. https://doi.org/10.1126/science.7985020

Fauser, B. C. (2019). Towards the global coverage of a unified registry of IVF outcomes. Reproductive Biomedicine Online, 38(2), 133-137. https://doi.org/10.1016/j.rbmo.2018.12.001

Fauser, B. C., Devroey, P., \& Macklon, N. S. (2005). Multiple birth resulting from ovarian stimulation for subfertility treatment. The Lancet, 365, 1807-1816. https://doi.org/10.1016/S0140-6736(05)66478-1

Fujiwara, H. (2009). Do circulating blood cells contribute to maternal tissue remodeling and embryo-maternal cross-talk around the implantation period?. Molecular Human Reproduction, 15(6), 335-343. https://doi.org/10.1093/molehr/gap027

Gallos, I. D., Eapen, A., Price, M. J., Sunkara, S. K., Macklon, N. S., Bhattacharya, S., ... \& Coomarasamy, A. (2017). Controlled ovarian stimulation protocols for assisted reproduction: a network meta-analysis. The Cochrane Database of Systematic Reviews, 2017(3), CD012586. https://doi.org/10.1002/14651858.CD012586

Jungheim, E. S., Meyer, M., \& Broughton, D. E. (2015, March). Best practices for controlled ovarian stimulation in IVF. Seminars in Reproductive Medicine, 33(2), 77-82. https://doi.org/10.1055/s-0035-1546424

Kolibianakis, E., Bourgain, C., Albano, C., Osmanagaoglu, K., Smitz, J., Van Steirteghem, A., \& Devroey, P. (2002). Effect of ovarian stimulation with recombinant follicle-stimulating hormone, gonadotropin releasing hormone antagonists and human chorionic gonadotropin on endometrial maturation on the day of oocyte pick-up. Fertility and Sterility, 78(5), 1025-1029. https://doi.org/10.1016/S0015-0282(02)03323-X 
Ku, S. Y., Choi, Y. M., Suh, C. S., Kim, S. H., Kim, J. G., Moon, S. Y., \& Lee, J. Y. (2002). Effect of gonadotropins on human endometrial stromal cell proliferation in vitro. Archives of Gynecology and Obstetrics, 266(4), 223-228. https://doi.org/10.1007/s00404-002-0292-9

La Marca, A., Carducci Artenisio, A., Stabile, G., Rivasi, F., \& Volpe, A. (2005). Evidence for cycledependent expression of follicle-stimulating hormone receptor in human endometrium. Gynecological Endocrinology, 21(6), 303-306. https://doi.org/10.1080/09513590500402756

Lai, T. H., Lee, F. K., Lin, T. K., Horng, S. G., Chen, S. C., Chen, Y. H., \& Wang, P. C. (2009). An increased serum progesterone-to-estradiol ratio on the day of human chorionic gonadotropin administration does not have a negative impact on clinical pregnancy rate in women with normal ovarian reserve treated with a long gonadotropin releasing hormone agonist protocol. Fertility and Sterility, 92(2), 508-514. https://doi.org/10.1016/j.fertnstert.2008.06.036

LaPolt, P. S., Tilly, J. L., Aihara, T. O. S. H. I. H. I. K. O., Nishimori, K. E. I. J. I., \& Hsueh, A. J. (1992). Gonadotropin-induced up-and down-regulation of ovarian follicle-stimulating hormone (FSH) receptor gene expression in immature rats: effects of pregnant mare's serum gonadotropin, human chorionic gonadotropin and recombinant FSH. Endocrinology, 130(3), 1289-1295. https://doi.org/10.1210/endo.130.3.1537292

Lawrenz, B., \& Fatemi, H. M. (2017). Effect of progesterone elevation in follicular phase of IVFcycles on the endometrial receptivity. Reproductive Biomedicine Online, 34(4), 422-428. https://doi.org/10.1016/j.rbmo.2017.01.011

Macklon, N. S., Stouffer, R. L., Giudice, L. C., \& Fauser, B. C. (2006). The science behind 25 years of ovarian stimulation for in vitro fertilization. Endocrine Reviews, 27(2), 170-207. https://doi.org/10.1210/er.2005-0015

Marci, R., Graziano, A., Lo Monte, G., Piva, I., Soave, I., Marra, E., ... \& Caserta, D. (2013). GnRH antagonists in assisted reproductive techniques: a review on the Italian experience. European Review for Medical and Pharmacological Sciences, 17(7), 853-73. http://www.europeanreview.org/wp/wpcontent/uploads/853-873.pdf

Massimiani, M., Lacconi, V., La Civita, F., Ticconi, C., Rago, R., \& Campagnolo, L. (2020). Molecular signaling regulating endometrium-blastocyst crosstalk. International Journal of Molecular Sciences, 21(1), 23. https://doi.org/10.3390/ijms21010023
Ponikwicka-Tyszko, D., Chrusciel, M., Stelmaszewska, J., Bernaczyk, P., Sztachelska, M., Sidorkiewicz, I., ... \& Rahman, N. A. (2016). Functional expression of FSH receptor in endometriotic lesions. The Journal of Clinical Endocrinology \& Metabolism, 101(7), 29052914. https://doi.org/10.1210/jc.2016-1014

Sahar, N., Mujihartini, N., Pudjianto, D. A., Pradhita, A. D., Thuffi, R., \& Kusmardi, K. (2019a). Increased Progesterone on the Day of Administration of hCG in Controlled Ovarian Hyperstimulation Affects the Expression of HOXA10 in Primates' Endometrial Receptivity. Biomedicines, 7(4), 83. https://doi.org/10.3390/biomedicines7040083

Sahar, N., Rachman, I. A., Muharram, R., Siregar, N. C., Kusmardi, K., Mudjihartini, N., ... \& Thuffi, R. (2019b). Endometrial $\alpha v \beta 3$ Integrin Expression in Macaca nemestrina Endometrium after Gonadotrophin Administration for Controlled Ovarian Hyperstimulation. Journal of International Dental and Medical Research, 12(4), 1644-1651. http://www.jidmr.com/journal/wpcontent/uploads/2019/12/68.MB6-19388-ED-2OK.pdf

Sakiner, L., Bulut, I. D., Yalcinkaya, P., \& Elmas, C. (2018). Effects of controlled ovarian hyperstimulation protocols on uterine markers. Journal of Turgut Ozal Medical Center, 25(3). 495-498. https://doi.org/10.5455/annalsmedres.2018.04.064

Simon, A., \& Laufer, N. (2012). Repeated implantation failure: Clinical approach. Fertility and sterility, 97(5), 1039-1043. https://doi.org/10.1016/j.fertnstert.2012.03.010

Simon, C., Martín, J. C., \& Pellicer, A. (2000). Paracrine regulators of implantation. Best Practice \& Research Clinical Obstetrics \& Gynaecology, 14(5), 815-826. https://doi.org/10.1053/beog.2000.0121

Simoni, M., Gromoll, J., \& Nieschlag, E. (1997). The follicle-stimulating hormone receptor: biochemistry, molecular biology, physiology and pathophysiology. Endocrine Reviews, 18(6), 739-773. https://doi.org/10.1210/edrv.18.6.0320

Van Mourik, M. S., Macklon, N. S., \& Heijnen, C. J. (2009). Embryonic implantation: cytokines, adhesion molecules and immune cells in establishing an implantation environment. Journal of Leukocyte Biology, 85(1), 4-19. https://doi.org/10.1189/jlb.0708395

Zhang, D., Li, J., Xu, G., Zhang, R., Zhou, C., Qian, Y., ... \& Huang, H. (2015). Follicle-stimulating hormone promotes age-related endometrial atrophy through cross-talk with transforming growth factor beta signal transduction pathway. Aging Cell, 14(2), 284-287. https://doi.org/10.1111/acel.12278 